Pittsburgh University School of Law

Scholarship@PITT LAW

$11-14-2019$

\title{
Snapback, Version 2.0: The Best Solution to the Problem of Snap Removal
}

Arthur D. Hellman

University of Pittsburgh School of Law, hellman@pitt.edu

Follow this and additional works at: https://scholarship.law.pitt.edu/fac_testimony

Part of the Civil Procedure Commons, Courts Commons, Judges Commons, Jurisdiction Commons, Law and Politics Commons, Law and Society Commons, and the Torts Commons

\section{Recommended Citation}

Arthur D. Hellman, Snapback, Version 2.0: The Best Solution to the Problem of Snap Removal, Supplementary Statement to the Hearing Before the House Committee on the Judiciary -- Subcommittee on Courts, Intellectual Property, and the Internet (2019).

Available at: https://scholarship.law.pitt.edu/fac_testimony/8

This Response or Comment is brought to you for free and open access by the Faculty Publications at Scholarship@PITT LAW. It has been accepted for inclusion in Testimony by an authorized administrator of Scholarship@PITT LAW. For more information, please contact leers@pitt.edu, shephard@pitt.edu. 


\title{
Snapback, Version 2.0: The Best Solution to the Problem of Snap Removal
}

\author{
Arthur D. Hellman
}

\begin{abstract}
The forum defendant rule, embodied in 28 U.S.C. $§ I 44 I(b)(2)$, prohibits removal of civil actions based on diversity of citizenship jurisdiction "if any of the parties in interest properly joined and served as defendants is a citizen of the State in which such action is brought." Pointing to the phrase "properly joined and served," defendants have argued that $\S I 44 I(b)(2)$ does not bar removal of a diversity action if a citizen of the forum state has been joined as a defendant but has not yet been served. The stratagem of removing before service to avoid the prohibition of $\S I 44 I(b)(2)$ is known as "snap removal." Two courts of appeals and many district judges have held that snap removal is permissible; other district judges have held that it is not.

On November 14, 2019, the Subcommittee on Courts, Intellectual Property, and the Internet of the House Judiciary Committee held a hearing to examine the practice of snap removal. Three of the four witnesses agreed that snap removals are contrary to the intent of Congress as manifested in the forum defendant rule and that action by Congress is needed to close the loophole. Two different kinds of action were suggested. Professor James Pfander offered three proposals, each of which would require amending the text of an existing subsection of the Judicial Code. I offered one proposal, a standalone addition to the Code that would create what has been called a "snapback" mechanism.
\end{abstract}

The snapback mechanism is designed to operate as a kind of time machine. It sends the parties back to where they were at the moment before the defendant snapremoved, and it gives the plaintiff a chance to complete the service of process that would have prevented the removal under $\S$ I44I(b)(2). The case stays in federal court only long enough for the plaintiff to take the steps that will allow the case to return to state court, where all further proceedings will take place.

I believe that the snapback mechanism will address the problem described at the hearing without opening new loopholes or generating uncertainty about other aspects of removal practice. In contrast, each of the alternative proposals would create serious risks of reopening settled law and disrupting removal practice in ways that cannot be anticipated.

On February 7, 2020, Rep. Henry C. "Hank” Johnson, Jr., Chairman of the Subcommittee, introduced H.R. 580I, the "Removal Jurisdiction Clarification Act of 2020. H.R. 580 I embodies a revised version of the snapback proposal outlined at the hearing. 
This supplementary statement addresses the major issues raised at the hearing. Part I analyzes the proposals offered by Professor Pfander. Part II offers a revised version of the snapback proposal, with commentary on the policy and drafting choices that it reflects. Part III responds briefly to the arguments made by the hearing witness who disputed the need for legislative action. In particular, the statement discusses the counterpart stratagem used by plaintiffs to defeat removal - artful or "fraudulent" joinder of non-diverse or forum defendants. I suggest that Congress should address both problems in a way that respects the purpose of the constitutionally authorized diversity jurisdiction. Part IV addresses Professor Pfander's tentative suggestion that Congress "assign some authority over the details of removal and remand procedure to a rule-making body within the Judicial Conference of the United States." 


\title{
Supplementary Statement of
}

\author{
Arthur D. Hellman \\ Professor of Law Emeritus \\ University of Pittsburgh School of Law
}

House Committee on the Judiciary

Subcommittee on Courts, Intellectual Property, and the Internet

Hearing on

Examining the Use of "Snap" Removals to

Circumvent the Forum Defendant Rule

November 14, 2019*

Arthur D. Hellman

University of Pittsburgh School of Law

Pittsburgh, PA 15260

Telephone: 4I 2-648-1340

Fax: 4I 2-648-2649

E-mail: hellman@pitt.edu

* On February 4, 2020, Representative Henry C. "Hank" Johnson, Jr., the Chairman of the Subcommittee, invited me to submit "additional points or submissions ... in response to the questions asked at the hearing." This Supplementary Statement responds to that invitation. 


\section{Outline** $^{* *}$}

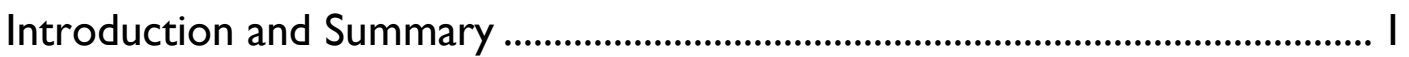

I. Text Editing or a Standalone Fix? ........................................................................ 2

A. Text editing and the risk of unintended consequences ......................... 3

B. Three text-editing proposals....................................................................... 4

I. Deleting the service requirement in 28 U.S.C. $\S 224$ I(b)(2) ..... 4

2. Making the forum defendant rule jurisdictional .............................. 6

3. Prohibiting removal before service................................................ 8

C. Prevention and cure ................................................................................. 9

II. Snapback: The Preferable Solution ................................................................... 10

A. New subsection in 28 U.S.C. $\S$ I 447...................................................... I I

I. Structure of the proposed new subsection .................................... 12

2. Policy choices in the snapback provision........................................ 13

3. Drafting choices in the snapback provision .................................. 14

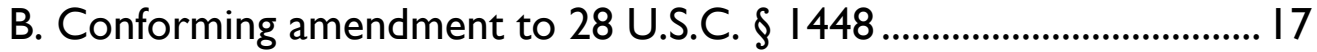

C. Effective date provision............................................................................ 17

III. A Brief Response to Lawyers for Civil Justice .............................................. 18

IV. Clarifying the Law of Federal Jurisdiction: Finding a Better Process ....... 2 I

** Thanks to Steven Gensler, Lonny Hoffman, James E. Pfander, Thomas D. Rowe, Jr., Joan Steinman, and, especially, Brendan McDonough for comments on earlier drafts of this supplementary statement and of the revised statutory proposal it contains. 


\section{Introduction and Summary}

The forum defendant rule, embodied in 28 U.S.C. $§ I 44 I(b)(2)$, prohibits removal of civil actions based on diversity of citizenship jurisdiction "if any of the parties in interest properly joined and served as defendants is a citizen of the State in which such action is brought." Pointing to the phrase "properly joined and served," defendants have argued that $\S I 44 \mid(b)(2)$ does not bar removal of a diversity action if a citizen of the forum state has been joined as a defendant but has not yet been served. The stratagem of removing before service to avoid the prohibition of $\S I 44 I(b)(2)$ is known as "snap removal." Two courts of appeals and many district judges have held that snap removal is permissible; other district judges have held that it is not.

On November 14, 2019, the Subcommittee on Courts, Intellectual Property, and the Internet of the House Judiciary Committee held a hearing to examine the practice of snap removal.' Three of the four witnesses agreed that snap removals are contrary to the intent of Congress as manifested in the forum defendant rule and that action by Congress is needed to close the loophole. ${ }^{2}$ Two different kinds of action were suggested. Professor James Pfander outlined three proposals, each of which would require amending the text of an existing subsection of the Judicial Code. ${ }^{3}$ I offered one proposal, a standalone addition to the Code that would create what has been called a "snapback" mechanism.

The snapback mechanism is designed to operate as a kind of time machine. It sends the parties back to where they were at the moment before the defendant snap-removed, and it gives the plaintiff a chance to complete the service of process that would have prevented the removal under $\S I 44 I(b)(2)$. The case stays in federal court only long enough for the plaintiff to take the steps

I This supplementary statement assumes familiarity with the issue as discussed in the statements submitted for the hearing record. All of the statements, as well as a webcast of the hearing, can be found at https://judiciary.house.gov/legislation/hearings/examining-use-snapremovals-circumvent-forum-defendant-rule. Parts I through III of my statement provide background. See https://papers.ssrn.com/sol3/papers.cfm?abstract id=34892 I3.

2 The fourth witness disputed the existence of a problem requiring Congressional action. For a brief response to his arguments, see infra Part III.

3 All references to Professor Pfander's statement are to the text posted on the House Judiciary Committee website. https://docs.house.gov/meetings/]U/JU03/2019| | | 4/ I 10208/HHRG- | |6-JU03-Wstate-Pfander]20191114.pdf. 


\section{Hellman - Snap Removal Supp - Page 2}

that will allow the case to return to state court, where all further proceedings will take place.

I believe that the snapback mechanism will address the problem described at the hearing without opening new loopholes or generating uncertainty about other aspects of removal practice. In contrast, each of the alternative proposals would create serious risks of reopening settled law and disrupting removal practice in ways that cannot be anticipated.

On February 7, 2020, Rep. Henry C. "Hank" Johnson, Jr., Chairman of the Subcommittee, introduced H.R. 580I, the "Removal Jurisdiction Clarification Act of 2020." 4 H.R. 580 I embodies a revised version of the snapback proposal outlined at the hearing. ${ }^{5}$

This supplementary statement addresses the major issues raised at the hearing. Part I analyzes the proposals offered by Professor Pfander. Part II offers a revised version of the snapback proposal, with commentary on the policy and drafting choices that it reflects. Part III responds briefly to the arguments made by the hearing witness who disputed the need for legislative action. Part IV addresses Professor Pfander's tentative suggestion that Congress "assign some authority over the details of removal and remand procedure to a rule-making body within the Judicial Conference of the United States."

\section{Text Editing or a Standalone Fix?}

In his statement for the hearing, Professor Pfander offered three proposals that he characterized as "preventative" approaches to snap removal.6 As already noted, each of the three would require amending the text of an existing section of the Judicial Code. Professor Pfander acknowledged that the text editing approach implicates "the problem of unintended consequences" and runs "the risk of inadvertently creating new problems." That cautionary note applies to all three of the "preventative" proposals in the statement. In addition, each of the three is problematic in its own way.

4 The bill has 13 co-sponsors, including Rep. Jerrold Nadler, Chairman of the Judiciary Committee.

5 For the text of the bill, see https://www.congress.gov/l |6/bills/hr580I/BILLS$116 \mathrm{hr} 580 \mathrm{lih} . \mathrm{pdf}$.

6 Professor Pfander has authorized me to say that in his statement he was offering possible approaches developed by others to be considered by the Committee. He was not necessarily endorsing any of the proposals he described. 


\section{A. Text editing and the risk of unintended consequences}

As I suggested in my initial statement, any attempt to change the law through what might be called "text editing" - adding, deleting, or changing words in existing statutory text - runs a serious risk of inadvertently unsettling other doctrines of removal law. Removal law is complex and interconnected. The statutory language provides only a framework; most of the law is contained in a vast corpus of decisions, many of which deal with issues that remain almost invisible because they have never reached the Supreme Court.

The dangers inherent in the text-editing approach are exemplified by a recent development involving the Removal Clarification Act of 20II. A "conforming amendment" that was part of the Act inserted three words - "or relating to" - into the preexisting text of the federal officer removal statute, 28 U.S.C. $\S 1442(a)(I)$. The purpose of adding the three words was very narrow:

to clarify that state pre-suit discovery proceedings are removable even though the state proceeding is not technically "for" the conduct of a federal officer performing his or her official work, but merely seeks information from the federal officer, that is, the proceeding is a of a type that "relates to" the conduct of a federal officer. ${ }^{7}$

That limited purpose was understood by all participants in the drafting process and was made explicit at the hearing on a predecessor bill. ${ }^{8}$ The language was reviewed by two law professors (including myself), the General Counsel of the House of Representatives, and a Deputy Assistant Attorney General in the Department of Justice. No one thought that the bill, or the three-word insertion, would do more than fix the narrow problem that was the subject of the hearing. Indeed, the principal drafter of the bill emphasized that " $[t]$ he bill leaves in place the current law and practices governing federal officer removal in nearly all respects." 9

Notwithstanding this careful process, several courts have interpreted the three-word insertion to effect a significant expansion of the right of removal,

7 En Banc Amicus Curiae Brief of U.S. Congressman Henry C. “Hank” Johnson, Jr., in Support of Appellee and Affirmance at 10, Latiolais v. Huntington Ingalls, Inc., No. 18-30652 (5th Cir. July 12, 2019). Rep. Johnson was the sponsor of the bill.

8 See id. at 10-12 (summarizing statements at hearing).

9 H.R. 528I, "Removal Clarification Act of 2010": Hearing Before the Subcommittee on Courts and Competition Policy of the House Committee on the Judiciary at 16 (2010) (statement of Irving Nathan). 
available not only to government officials, but also to government contractors. 10 There could not be a better illustration of the "unintended consequences" that can flow from revising a longstanding statutory text. Congress should not pursue that approach when a narrowly tailored fix is available, as it is here.

\section{B. Three text-editing proposals}

Apart from the general concern about unintended consequences, each of the proposals outlined by Professor Pfander raises problems of its own.

\section{Deleting the service requirement in 28 U.S.C. $§ 224$ I (b)(2)}

The first proposal discussed by Professor Pfander is to delete the words "and served" from the phrase "properly joined and served" in $§ I 44 I$ (b)(2). Preliminarily, Professor Pfander's cautionary note about unintended consequences applies in full force to this suggestion. The language in question "properly joined and served" - has been part of the statute for more than 70 years. " Hundreds of decisions have interpreted it. No one can be certain which judicial constructions would be called into question if the language were altered. It is simply not possible to turn the clock back to 1948, before the current wording was adopted, and restore whatever understanding may have existed of the words "properly joined" without "and served."

But it is not necessary to rely solely on the risk of unintended consequences, because there are also particular reasons for not abrogating the service requirement in $\S$ I 44I(b)(2). As the Third Circuit explained, Congress adopted the "properly joined and served" language "to prevent a plaintiff from blocking removal by joining as a defendant a resident party against whom it does not intend to proceed, and whom it does not even serve." 12 Deleting the words "and served" would encourage the gamesmanship that Congress intended to prevent when it added the words in 1948.

Moreover, abrogating the service requirement of $\S$ I44I(b)(2) would not necessarily eliminate litigation over compliance with the forum defendant rule, at

10 See Latiolais v. Huntington Ingalls, Inc., 918 F.3d 406, 4I3-I4 (5th Cir. 20I9) (Jones, J. concurring) (citing cases), rehearing en banc granted, 923 F.3d 427 (5th Cir. 2019).

II The wording of the statute was changed by the Federal Courts Jurisdiction and Venue Clarification Act of 20I I, but the phrase "properly joined and served" was retained intact.

12 Encompass Ins. Co. v. Stone Mansion Restaurant Inc., 902 F.3d I47, I53 (3rd Cir. 2018) (citation omitted). 
least where the plaintiff sues both forum and non-forum defendants. To be sure, in that situation, none of the defendants could attempt snap removal. But if the plaintiff has asserted insubstantial or thinly grounded claims against the forum defendant, the out-of-state defendant might remove anyway based on an argument that the local defendant has been improperly - i.e. fraudulently - joined. ${ }^{13}$ Litigating that question is likely to be more difficult and costly than litigating snap removal. ${ }^{14}$ Indeed, the Second Circuit made that very point:

Congress may well have adopted the "properly joined and served" requirement in an attempt to both limit gamesmanship and provide a bright-line rule keyed on service, which is clearly more easily administered than a fact-specific inquiry into a plaintiff's intent or opportunity to actually serve a home-state defendant. ${ }^{15}$

Professor Pfander downplays the concern that deleting the "and served" language "would encourage the assertion of more frivolous claims against jurisdictional spoilers." He believes that the fraudulent joinder doctrine will limit "attempts by plaintiffs to join jurisdictional spoilers to prevent removal." But in making this argument, he explicitly assumes that to defeat removal when the defendant asserts fraudulent joinder, "the plaintiff must assert substantial claims against all of the [spoiler] parties." (Emphasis added.) That is not the law in any

13 Although the fraudulent joinder doctrine is more frequently applied to defendants who share citizenship with the plaintiff, it also comes into play when the "spoiler" is a citizen of the forum state, and the doctrine is generally applied in the same way. As a district court in Missouri observed a few years ago, "The standards for determining whether a resident defendant is fraudulently joined are the same as the standards for determining whether a diversity-destroying defendant is fraudulently joined." Byrd v. TVI, Inc., 2015 WL 5568454 (E.D. Mo. Sept. 2I, 20I5) (emphasis added). Accord, In re Ethicon, Inc., Pelvic Repair Sys. Prods. Liab. Litig., 20I3 WL 67I0345 at *3 n. 2 (S.D. W. Va. Dec. 19, 20I3) ("In Musewicz, the issue is diversity of citizenship, while in Hammons and Delacruz, the issue is the home state defendant rule. However, the fraudulent joinder analysis remains the same in both instances."); Aguayo v. AMCO Ins. Co., 59 F. Supp. 3d I225, 1257 (D. N.M. 20I4) ("the Court sees no principled reason to limit fraudulent-joinder doctrine's application to the joining of nondiverse parties to defeat complete diversity, while excluding the functionally identical practice of fraudulently joining forum-citizen defendants to defeat the forum-defendant rule."). But see Morris v. Nuzzo, 7 I8 F.3d 660 (7th Cir. 20I2) (questioning equivalence but not deciding the issue).

14 In some cases in which courts have allowed snap removal, the court noted that it did not need to address the defendant's alternative argument that the "spoiler" had been fraudulently joined. E.g., Howard v. Crossland Const. Co., 2018 WL 2463099 at *3 (N.D. Okla. June I, 2018); Pathmanathan v. Jackson Nat'l Life Ins. Co., 2015 WL 4605757 at *5 n. I (M.D. Ala. July 30, 20I5).

15 Gibbons v. Bristol-Myers Squibb Co., 919 F.3d 699, 706 (2nd Cir. 2019) 
circuit. Far from it; typically the defendant must show that there is "no possibility" that state law would impose liability on the spoiler. ${ }^{16}$ The fraudulent joinder doctrine thus provides little protection against the assertion of insubstantial claims against a spoiler as a means of precluding removal through the forum defendant rule. ${ }^{17}$

It would be a serious mistake for Congress to abandon the "bright-line rule keyed on service" in order to combat abuse of the rule by a relatively small number of defendants. The far better approach is to enact a standalone provision that limits snap removal without encouraging gamesmanship by plaintiffs or disrupting other aspects of removal law.

\section{Making the forum defendant rule jurisdictional}

The second proposal offered by Professor Pfander is to make the forum defendant rule jurisdictional - "to fram[e] the barrier to removal of cases involving forum defendants in jurisdictional terms." If that were done, he explains, the forum defendant rule would "resemble the jurisdictional rule of complete diversity, which operates as a barrier to removal that snap removal cannot overcome."

This would be a substantial change from current law, and in my view a highly undesirable one. In all but one of the ten circuits to have considered the question, the courts of appeals have held that the forum defendant rule is not jurisdictional. ${ }^{18}$ Although the courts have decided the question as one of statutory construction, they have also adverted to policy concerns. For example,

16 See, e.g., Henderson v. Washington Nat'l Ins. Co., 454 F.3d I278, I 283 (I I th Cir. 2006) ("we may deny the motion [to remand a case on fraudulent grounder grounds] only if the defendants have proven by clear and convincing evidence ... that there is no possibility that [plaintiff] can establish a cause of action against the resident defendant") (cleaned up) (emphasis in original); In re Briscoe, 448 F.3d 20I, 217 (3rd Cir. 2006) ("if there is even a possibility that a state court would find that the complaint states a cause of action against any one of the resident defendants, the federal court must find that joinder was proper and remand the case to state court") (emphasis added). Even under the Innocent Party Protection Act, passed by the House in 2017, the defendant would have to show that the claim against the spoiler was "not plausible." See H.R. 725, I I5th Cong. $§ 2$ (2017). That certainly would not require the plaintiff to show that the claim was "substantial."

17 For further discussion of fraudulent joinder, see infra Part III.

18 See Lively v. Wild Oats Markets, Inc., 456 F.3d 933, 940 (9th Cir. 2006) (collecting cases). The outlier is the Eighth Circuit. See Horton v. Conklin, 43I F.3d 602, 605 (8th Cir. 2005); see also infra note 20 . 
as the Ninth Circuit observed, a procedural characterization of the forum defendant rule honors the purpose of the rule, "because the plaintiff can either move to remand the case to state court within the 30-day time limit [of $\S$ 1447(c)], or allow the case to remain in federal court by doing nothing. Either way, the plaintiff exercises control over the forum." 19

Making the forum defendant rule jurisdictional would mean that the rule could never be waived or forfeited, no matter how late in the litigation the presence of a forum defendant was discovered. ${ }^{20}$ It would be equally irrelevant that one of the parties had deliberately concealed facts relating to its citizenship. ${ }^{21}$ A rigid rule of that kind would be particularly troublesome in an era when litigation often involves unincorporated associations, whose citizenship is determined by the citizenship of each of its members. ${ }^{22}$ There are LLCs whose members are LLCs, and so forth up the chain. ${ }^{23}$ It would be extremely inefficient if, after years of litigation, the parties had to start all over again because no one had previously realized that one ultimate non-LLC member was a citizen of the forum state. ${ }^{24}$

As with the first proposal in Professor Pfander's statement, this one would affect a wide range of cases in which no defendant is abusing the forum defendant rule. Congress should not take that step unless there is no other way to combat the abuse.

19 Lively, 456 F.3d at 940.

20 See Doe XY v. Shattuck-St. Mary's School, 2015 WL 269034 *I (D. Minn. Jan. 2I, 20I5) (plaintiff asserted that violation of forum defendant rule was harmless, and he did "not object to remaining in federal court," but court found that "remand cannot be avoided" because Eighth Circuit treats the forum defendant rule as jurisdictional).

2I See Owen Equipment Co. v. Kroger, 437 U.S. 365, 377 n.2I (1978) ("Our holding is that the District Court lacked power to entertain the respondent's lawsuit against the petitioner. Thus, the asserted inequity in the respondent's alleged concealment of its citizenship is irrelevant.").

22 See, e.g., Zambelli Fireworks Mfg. Co. v. Wood, 592 F.3d 4I2, 420 (3d Cir. 2010).

23 See id. (noting that "where an LLC has, as one of its members, another LLC, the citizenship of unincorporated associations must be traced through however many layers of partners or members there may be to determine the citizenship of the LLC”) (cleaned up).

24 I recognize that a proposed amendment to the Federal Rules of Civil Procedure (currently in the public-comment stage) would require a party in a case based on diversity jurisdiction to disclose the citizenship of "every individual or entity whose citizenship is attributed to that party at the time the action is filed." Even if the rule is adopted, complex ownership arrangements could still result in inadvertent mischaracterizations of citizenship. 
Hellman - Snap Removal Supp - Page 8

\section{Prohibiting removal before service}

The third text-editing proposal is that Congress amend $\S$ I 446 to prohibit removal before the removing defendant has been served. This suggestion - which Professor Pfander credits to Professor Kevin Clermont of Cornell Law School would, like the others, constitute a sharp departure from current law. The Court of Appeals for the First Circuit, in a thorough opinion four years ago, found that "every one" of the federal courts to consider the question since the Supreme Court construed the statute in 199925 had concluded "that formal service is not generally required before a defendant may file a notice of removal." 26

Professors Clermont and Pfander seem to suggest that prohibiting removal before service would be easy to implement, but I do not think that is so. The limitation would be an amendment to either $\S$ I446(a) or $\S$ I446(c)(2). ${ }^{27}$ Congress would have to integrate the new prohibition with the carefully constructed timing scheme enacted in the Federal Courts Jurisdiction and Venue Clarification Act of 20I I (JVCA). I helped to draft the JVCA, and I can testify that it took quite a bit of effort to get all of the moving parts in $\S$ I 446 to fit together. The task would be even more complex if Congress had to consider another set of moving parts for the starting dates for the removal periods. And the greater the complexity, the higher the likelihood that the drafters will miss some combination of circumstances and create new problems and litigation points down the line.

The prospect of unintended consequences looms especially large because the proposed amendment to $\S$ 1446(a) would not be limited in its application to snap removals. The new prohibition would apply to all diversity removals, all federal question removals, and indeed to federal officer removals under $\S 1442$. To be sure, Professors Clermont and Pfander contemplate that the restriction might be limited to diversity suits. Yet even if that were done, the new law would still apply not only to evasive defendants like the medical device companies whose stratagems were described at the hearing, but also to defendants with completely legitimate grounds for removal who have a right to be in federal court and want to get there as soon as possible.

25 See Murphy Bros., Inc. v. Michetti Pipe Stringing, Inc., 526 U.S. 344 (1999).

26 Novak v. Bank of N.Y. Mellon Trust Co. N.A., 783 F.3d 910, 914 (I st Cir. 2015).

27 The professors suggest the latter as a means of limiting the change to diversity suits, but the primary proposal is an amendment to $\S$ 1446(a), applicable to all removals of civil actions. See discussion infra. 


\section{Hellman - Snap Removal Supp - Page 9}

It would be a great mistake for Congress to change the law and impose this new limitation on all defendants - or even all defendants in diversity cases because a relatively small number of defendants have arguably abused the system in a narrow and discrete category of cases. (Not only narrow and discrete, but atypical - atypical in that the plaintiff has chosen to bring suit outside his or her home state. $)^{28}$ The better approach is to craft a precisely tailored fix that will solve the problem of snap removal without changing - or even raising questions about - other aspects of removal practice.

\section{Prevention and cure}

In his written statement and again in his testimony at the hearing, Professor Pfander invoked the adage that "an ounce of prevention is worth a pound of cure." I have worked with Professor Pfander on other projects, and I have great respect for him as a Federal Courts scholar. But I think that this suggestion is off the mark in two respects.

First, the adage about an ounce of prevention is certainly good advice in some circumstances - but not always. If the preventive medicine will have side effects, and you don't know how many people will experience them, or how bad they will be, it may be better to rely on the cure.

Second, and contrary to the premise of the Professor Pfander's comment, I think the snapback proposal will have substantial preventive effects. A defendant like the medical device manufacturer whose maneuvers were described at the hearing may be willing to direct its process receiver to hide from the process server for two or three hours. But would the corporation send the employee into hiding for two or three days? Or for two or three weeks? When at the end of that time the plaintiff will serve process and under the snapback provision the court must remand?

Such behavior would not only be futile; it would also risk antagonizing the federal judges in the corporation's home state. So I think that if the snapback provision is in effect, it will prevent most if not all snap removals. I turn now to the details of the snapback mechanism.

28 See infra Part III. 


\section{Snapback: The Preferable Solution}

The preferable legislative response to snap removal is a standalone addition to the Judicial Code that would allow the plaintiff to counter the stratagem by serving one or more in-state defendants after removal. Under this proposal, if the plaintiff takes that step within 30 days (or within the time for service under state law, if that is shorter) and moves to remand within the 30-day period specified by current $\S 1447(\mathrm{c})$, the district court must send the case back to state court.

The proposed solution has been called the "snapback." 29 It closes a loophole that Congress did not anticipate, without creating new loopholes or raising questions about other aspects of removal practice. Except for a minor conforming amendment, it makes no changes in the existing law of removal. ${ }^{30} \mathrm{In}$ particular:

- The forum defendant rule is retained in its present form. It prevents removal if even one properly joined and served defendant is a citizen of the forum state.

- If a defendant removes in violation of the forum defendant rule, the plaintiff can secure remand under $\S$ I447(c), as the plaintiff can do today.

- If the plaintiff is content to stay in federal court, the plaintiff can complete service under 28 U.S.C. $\S 1448$, again in accordance with current practice. ${ }^{31}$

All that is new is that the plaintiff can secure remand in the narrow class of situations where an in-state defendant has been properly joined, but the defendant removes before any in-state defendant has been properly served. ${ }^{32}$

The proposal is based in large part on the draft legislation included in an article authored by five Federal Courts scholars and published in the Federal

29 As noted in my hearing statement, credit for suggesting this term goes to Professor Steven Gensler of the University of Oklahoma Law School.

30 The new subsection would implicitly confirm that the forum defendant rule is not jurisdictional. This would codify decisional law in all but one of the circuits to have considered the question. For discussion, see infra Parts I-A-I \& II-A-3.

3I For discussion of $\S 1448$, see infra Part II-B.

32 Other advantages of the snapback approach are outlined in Part IV-C of my hearing statement. I will not repeat that discussion here. 
Courts Law Review in 2016.33 The proposal has been modified in several respects to address concerns expressed at the hearing and in post-hearing discussions. ${ }^{34}$

The proposal includes three elements: a new subsection to be added to 28 U.S.C. $\S ~ 1447$, the Judicial Code section that deals with procedures after removal; a conforming amendment to 28 U.S.C. $§$ I448; and an "effective date" provision.

\section{A. New subsection in 28 U.S.C. § 1447}

The principal element of the proposed fix is a new subsection ( $f$ ) to be added at the end of 28 U.S.C. $\S$ I 447. It would read as follows.

\section{(f) Removal before service on forum defendant}

(I) This subsection shall apply to any case in which

(A) a civil action was removed solely on the basis of the jurisdiction under section 1332(a) of this title, and

(B) at the time of removal, one or more parties in interest properly joined as defendants were citizens of the state in which such action was brought, but no such defendant had been properly served.

(2) The court shall remand the civil action described in paragraph (I) to the state court from which it was removed if -

(A) within 30 days after the filing of the notice of removal under section 1446(a), or within the time specified by state law for service of process, whichever is shorter, a defendant described in subparagraph (I)(B) is properly served in the manner prescribed by state law, and

(B) a motion to remand is made in accordance with, and within the time specified by, the first sentence of subsection (c).

Three aspects of this proposal deserve attention: the structure of the new subsection in 28 U.S.C. § 1447; policy choices that differ from those in the original proposal; and drafting choices.

33 See Arthur D. Hellman, Lonny Hoffman, Thomas D. Rowe, Jr., Joan Steinman, \& Georgene Vairo, Neutralizing the Stratagem of "Snap Removal": A Proposed Amendment to the Judicial Code, 9 Fed. Courts L. Rev. 103 (2016).

34 See infra note 40 and accompanying text. 


\section{Structure of the proposed new subsection}

The proposed new subsection contains two numbered paragraphs. Paragraph (I) describes the class of cases in which the snapback is permitted, and paragraph (2) specifies the actions by the plaintiff and the district court that will send the case back to state court.

The description in paragraph (I) is narrow and precise; it targets only the class of cases in which defendants have attempted snap removal. Because it is set off in a separate paragraph, it will make the provision easy to find. Because it is so narrow, it reduces to an absolute minimum the likelihood of inadvertently changing the law applicable to other cases.

Paragraph (2) delineates the two actions the plaintiff must take to invoke the snapback - serving one in-state defendant and making a motion to remand and makes clear that if the plaintiff takes those steps within the time periods specified, the district court must remand the case to the state court from which it was removed.

Conversely, if the plaintiff does not take both steps within the time period specified, $\S$ I447(f) gives the district court no authority to remand. The case is then controlled by other provisions of Chapter 89. In particular, if the plaintiff is content to litigate in federal court, all the plaintiff need do is to serve any unserved defendants (forum or non-forum) in accordance with the law that is otherwise applicable to removed cases. ${ }^{35}$ The case will then stay in federal court.

The availability of this last option necessarily establishes that the forum defendant rule is not jurisdictional. As already noted, that position accords with the decisions of all but one of the circuits that have considered the question. ${ }^{36}$ It also represents sound policy in light of the purpose of diversity jurisdiction to provide "a neutral forum for parties from different States." 37 By definition, the forum defendant rule comes into play only when the plaintiff is not a citizen of the forum state. ${ }^{38}$ To be sure, the plaintiff has filed the lawsuit in state court, but

35 See infra note 4 I \& Part II-B.

36 See supra Part I-B-2.

37 See Home Depot, Inc. v. Jackson, I39 S. Ct. I743, I 746 (2019) (noting that diversity jurisdiction provides "a neutral forum for parties from different States when the claims are grounded in state law.”).

38 If the plaintiff is a citizen of the forum state, the complete-diversity requirement would preclude a diversity suit against a forum defendant, and the forum defendant rule will be irrelevant. 
if, after removal, the plaintiff prefers the neutral federal forum, there is no reason not to accommodate that preference. As the Ninth Circuit commented in holding that the forum defendant rule is not jurisdictional, allowing the plaintiff to "exercise[] control over the forum" honors the purpose of the rule. ${ }^{39}$

\section{Policy choices in the snapback provision}

This version of the snapback proposal reflects two policy choices that warrant discussion. These relate to the manner of service and the deadline for perfecting the snapback. I believe that these policy choices - which as noted earlier diverge from those in the original proposal - go far toward answering the criticisms of that proposal made by Professor Pfander in his hearing statement. 40

Manner of service. The proposed legislation requires the plaintiff to serve at least one in-state defendant "in the manner prescribed by state law." The question arises: why not give the plaintiff the option of using the methods available under federal law - specifically, Rule 4 of the Federal Rules of Civil Procedure? After all, 28 U.S.C. $\S 1448$ gives plaintiff that option in the ordinary run of removed cases. ${ }^{41}$

The answer is that the object of the snapback is to put the parties in the position they would be if the defendant had not jumped the gun and removed before service on the in-state defendant. If the defendant had not jumped the gun, the plaintiff would of course have been required to comply with state methods of service. It therefore seems desirable to adhere to that requirement in the snapback.

Time limit for service. The proposed legislation requires the plaintiff to serve an in-state defendant within 30 days of removal or within the time provided by state law, whichever is shorter. Because it is not self-evident that that is the best approach, it will be useful to explain why the requirement has been defined in that way.

An alternative approach would require that an in-state defendant be served within the same 30-day period specified in subparagraph (2)(B) for filing the

39 See supra note 19 and accompanying text.

40 I appreciate the constructive criticisms by Professor Pfander and others, which have resulted in a substantially improved proposal.

4I Section I 448 authorizes the plaintiff to complete service begun in state court or to have "new process issued in the same manner as in cases originally filed in [the] district court." For further discussion of $\S$ I448, see infra Part II-B. 
motion to remand. That would mean that in a state like New Jersey, where state law requires service to be made within 15 days, the plaintiff would get more time than state law allows. That seems counter to both federalism and efficiency. In this setting, uniformity within the state is more important than uniformity throughout the nation.

At the other end, there is no reason to give more time than 30 days for service, even if state law would allow it. The view of the plaintiffs' bar is that 30 days from snap removal is more than enough time to complete service and file the motion to remand. If the plaintiffs' bar is satisfied with 30 days, it is hard to imagine anyone else arguing that the period should be extended.

Based on this reasoning, the new draft proposes that if a forum defendant is properly served within 30 days after the filing of the notice of removal, or within the time allowed by state law for service of process, whichever is shorter, the civil action will be subject to remand.

As noted at the outset, under the snapback proposal, the case stays in federal court only long enough for the plaintiff to take the steps that will allow the case to return to state court, where all further proceedings will take place. It therefore makes sense to keep the involvement of federal law to a minimum. That is the approach taken in this proposal with respect to both the timing and the manner of service of process.

\section{Drafting choices in the snapback provision}

In drafting the proposed $\S 1447(f)$, the language has been chosen for maximum integration with other provisions of Chapter 89 , particularly the forum defendant rule as embodied in 28 U.S.C. § I 44I(b)(2) .

Subparagraph (I)(A). This subparagraph specifies the first-level category of cases to which the paragraph applies. The language - "solely on the basis of the jurisdiction under section 1332(a) of this title" - is taken verbatim from $\S$ I 44 I (b)(2). Two comments are in order. First, it is not clear that the words "of this title" are necessary. Second, "under" could be replaced by "conferred by." Both changes would conform to the approach taken in the revision of 28 U.S.C. $\S$ 1446(c) by the Federal Courts Jurisdiction and Venue Clarification Act of $201 \mathrm{I}$. However, since new $\S I 447$ (f) is so closely related to $\S I 44 I$ (b)(2), it seems preferable to use the formulation in the latter. 
Subparagraph (I)(B). This subparagraph specifies the subcategory of diversity cases in which defendants have attempted snap removal: "at the time of removal, one or more parties in interest properly joined as defendants were citizens of the state in which such action was brought, but no such defendant had been properly served." Four drafting choices warrant comment.

First, the draft refers to "one or more parties in interest properly joined as defendants." This phrase slightly modifies the language of $\S I 44 I$ (b)(2), which refers to "any of the parties in interest properly joined ... as defendants." It would be possible to use the language of $\S I 44 I$ (b)(2) verbatim, but in this context "one or more" seems clearer. Moreover, "'one or more" fits better with the final reference to "no such defendant," discussed below.

Second, the draft refers to forum state citizenship "at the time of removal." The phrase is not included in $\S$ I 44I(b)(2), but it is implicit because $\S$ I 44I(b)(2) is a limit on the removal itself. In contrast, proposed new $\S$ I447(f) deals with steps to be taken after removal. It seems prudent to make clear that what counts is forum-state citizenship at the time of removal.

Third, the draft includes the phrase "but no such defendant had been properly served." This phrase is necessary for a complete definition of the subcategory. If even one forum defendant has been served, there is no need to invoke subsection ( $f$ ); the forum defendant rule itself will bar the removal. It is preferable to include the qualification to clearly define the universe of cases to which the new provision applies.

Finally, the subsection applies only when no forum defendant has been properly served. "Properly served" is the phrase used in $\S I 44 I$ (b)(2). If the forum defendant rule treats improper service as tantamount to no service, the snapback mechanism should do the same. ${ }^{42}$

Subparagraph (2)(A). This subparagraph requires that the defendant be "properly served in the manner prescribed by state law."

As already noted, "properly served" is the phrase used in $\S I 44 I(b)(2)$. Since new subsection ( $f$ ) is designed to protect the thrust of $\S I 44 I(b)(2)$, it seems desirable to use the same language.

42 I have found very few cases in which a defendant has argued that removal was not barred by the forum defendant rule because a forum defendant had not been properly served at the time of removal. E.g., Crawford v. Barr Pharmaceuticals, Inc., 2019 WL 3288I37 (D. N.J. Aug. 29,2008 ) (holding that service was proper under state law, so forum defendant rule barred removal). 
Some readers of earlier drafts suggested that "a manner" would be preferable to "the manner." The concern is that "the manner" would be read to imply that there is only one way under state law to accomplish service. But if state law, like Rule 4 of the Federal Rules of Civil Procedure, specifies different procedures for different types of defendants or different types of claims, "aㅡ manner" could be read as negating those specific directives. I think that "properly served in the manner prescribed by state law" is naturally and plausibly read to mean "properly served in the manner prescribed by state law for the particular defendant and the particular claim."

It should also be clear that "the manner" of service includes all procedural aspects of service, e.g., who may or must serve process, whether service by email or social media is permissible, or how service is to be made upon a corporation or other entity. "Manner of service" excludes timing requirements, which are specified in the first two phrases of subparagraph (2)(A).

Subparagraph (2)(B). This subparagraph requires that the motion to remand be made "in accordance with, and within the time specified by, the first sentence of subsection (c)." 43 The first sentence of $\S$ 1447(c) provides: "A motion to remand the case on the basis of any defect other than lack of subject matter jurisdiction must be made within 30 days after the filing of the notice of removal under section I446(a)." The snapback thus conforms to the timing requirement for motions to remand "on the basis of any defect other than lack of subject matter jurisdiction." This means that the plaintiff has 30 days to seek the remand.

The subparagraph also states that the remand motion must be made "in accordance with" the first sentence of $\S$ I447(c). This language should be read as further confirming that the forum defendant rule is not jurisdictional. As noted earlier, that conclusion is implicit in paragraph (2) as a whole, because the remand order is conditioned on the plaintiffs taking the two required steps within the specified time. ${ }^{44}$ But explicitly referencing the first sentence of $\S$ 1447(c) reinforces the point.

It may be argued that "in accordance with" would include the 30-day deadline in $\S$ I447(c), so that it is unnecessary to also say "within the time specified by." But the short deadline is such an important part of the legislation that it is desirable to specify it anyway.

43 This draft follows the model of $\S$ I 446 as revised by the JVCA and refers to "subsection (c)" rather than $\S 1447(\mathrm{c})$.

44 See supra Part II-A-I. 
Hellman - Snap Removal Supp - Page 17

\section{B. Conforming amendment to 28 U.S.C. $\$ 1448$}

The snap removal legislation should include a conforming amendment to 28 U.S.C. § I448, which has the title "Process after removal." Section 1448, by its terms, applies, inter alia, to "all cases removed from any State court to any district court ... in which any one or more of the defendants has not been served with process." That phrase precisely describes the cases covered by new $\S$ 1447(f). But $§ 1448$ allows service to be made "in the same manner as in cases originally filed in [the] district court." Under current law (Rule 4(m)), that would give the plaintiff 90 days, not 30 days, to serve unserved defendants. It is therefore necessary to amend $\S 1448$ so that it would begin: "Except as provided in section $1447(f)$, in all cases ..."

Some readers of prior drafts have expressed the view that the proposed conforming amendment is unnecessary. As I understand their position, it is that $\S$ I 448 is addressed to actions that will remain in federal court, while new $\S$ I447(f) is aimed at getting cases back to the state court in which they were filed. That is true, but it does not change the fact that the permissive rule of $\S 1448$, made applicable to "all cases" in which a defendant has not been served at the time of removal, is in conflict with the short deadline specified in $§ 1447(f)$ for the cases within its ambit. It is therefore necessary to make clear that the permissive rule of $\S 1448$ does not apply to snap removal cases covered by $\S$ I 447(f).

Under new $\S$ I447(f) and the conforming amendment, a plaintiff who is content to stay in federal court would still have 90 days to serve process on the in-state defendant. But if the plaintiff wants to use the snapback, he or she must serve within the shorter period specified by $\S$ I447(f)(2)(A).

\section{Effective date provision}

The snapback bill should include a section specifying the effective date of the new provision. In the Federal Courts Jurisdiction and Venue Clarification Act of $20 \mathrm{II}$, the amendments to Title 28 were made applicable to actions "commenced" 30 days after enactment; however, for removed cases, an action was deemed to commence "on the date the action ... was commenced, within the meaning of State law, in State court." (Emphasis added.) That is probably a good model for legislation dealing with snap removal. Thus, the section might read: "The amendments made by this Act shall take effect upon the expiration of the 30-day period beginning on the date of the enactment of this Act, and shall apply to any action commenced on or after such effective date. An action commenced in State court and removed to Federal court shall be deemed to commence on the 
Hellman - Snap Removal Supp - Page 18

date the action or prosecution was commenced, within the meaning of State law, in State court." 45

It may be possible to combine the two sentences into one, since the Act applies only to cases removed from state to federal court. But that would probably produce a cumbersome sentence.

There may be a concern that 30 days after enactment does not give sufficient notice to the practicing bar. I do not think this will be a problem. As noted in my hearing statement, snap removal situations will generally involve savvy and knowledgeable attorneys on both sides. We can expect that the attorneys would be following the progress of the snap removal legislation and would be ready when it is enacted.

Out of caution, Congress might choose to delay the effective date so that it would apply, for example, only to cases commenced in state court 60 days or more after enactment. But I think that the 30 days specified in the JVCA is sufficient.

\section{A Brief Response to Lawyers for Civil Justice}

As noted at the outset, three of the four witnesses at the hearing agreed that snap removal is a problem and that legislative action is desirable. The fourth witness was attorney Kaspar J. Stoffelmayr, testifying on behalf of Lawyers for Civil Justice, "a national coalition of law firms, corporations and defense trial lawyer organizations that promotes excellence and fairness in the civil justice system to secure the just, speedy, and inexpensive determination of civil cases." 46 Mr. Stoffelmayr argued that there is "no basis for doing away with the salutary provision permitting pre-service removal when the anomalous results are infrequent and can result in no injustice to the disappointed plaintiffs." I will comment on four of the points made by Mr. Stoffelmayr in support of this position.

45 The JVCA's effective-date provision referred to an "action or prosecution commenced in State court ..." The reference to prosecutions was necessary because the JVCA included amendments to the provisions dealing with removal of criminal cases. No such reference is needed for the snapback provision, which applies only to civil suits.

46 All references to Mr. Stoffelmayr's statement are to the text posted on the House Judiciary Committee website. https://docs.house.gov/meetings/JU/JU03/20191 | | 4/ I 10208/HHRG- | |6-JU03-WstateStoffelmayrK-2019|II4.pdf. 
First, Mr. Stoffelmayr argued that "pre-service removal is relatively rare." He relied on an empirical study by Valerie Nannery published in 2018.47 However, as another witness, attorney Ellen Relkin, pointed out, the empirical study looked only at cases removed to federal court "between January I, 20 I2, and December 3I, 20I4, before service on any defendant." 48 The cutoff period for the study was thus more than five years ago. Ms. Relkin testified that the incidence of snap removals has exploded in the years since then.

Ms. Relkin also pointed out that Ms. Nannery's study period antedated the two court of appeals decisions holding that snap removal is permissible. Defendants in those circuits (including the Third Circuit, the epicenter of snap removal even before the court of appeals ruling) now know that they will not have to persuade a district judge to allow the removal. ${ }^{49}$ There is thus every reason to believe that, without legislation, defendants will take advantage of the stratagem whenever they are in a position to do so.

Second, Mr. Stoffelmayr emphasized that snap removal can become an issue "only when the plaintiff, contrary to normal practice, has elected to file a lawsuit in a state court outside of the plaintiff's own home state." He is quite correct about that. ${ }^{50}$ But it is equally important to emphasize that the forum chosen is the home state of the defendant. The Supreme Court, in several recent decisions, has reiterated that defendants can always be sued in their home state no matter where the claims arose. ${ }^{51}$ Moreover, the home state may be the only state where plaintiffs from different states with similar claims can all join. ${ }^{52}$ Allowing the plaintiffs to sue together in the defendant's home state makes for efficiency.

47 See Valerie M. Nannery, Closing the Snap Removal Loophole, 86 U. Cin. L. Rev. 54I (20I8). 48 Id. at 559.

49 District court decisions are not binding on other judges within the district. Whether snap removal was allowed thus depended on which judge was drawn - typically by lot - to hear the case.

50 See supra note 38 .

5 I See, e.g., Daimler AG v. Bauman, 57I U.S. I I7, I37 (2014) (noting that the state of incorporation and the state where the corporation has its principal place of business "afford plaintiffs recourse to at least one clear and certain forum in which a corporate defendant may be sued on any and all claims") (emphasis added).

52 A Supreme Court decision in 2018 narrowed plaintiffs' options in that respect. See Bristol-Myers Squibb Co. v. Superior Court, I37 S. Ct. 1773 (2018) (holding that a California state court could not exercise specific personal jurisdiction over claims by non-resident consumers against a defendant incorporated in Delaware and headquartered in New York). 
Third, in response to a question at the hearing, I commented that the forum defendant rule rests on the assumption that as long as there is at least one defendant from the forum state, no defendant in the case needs protection from bias at the hands of the state court. Snap removal, I said, is inconsistent with that assumption. Mr. Stoffelmayr took issue with the assumption. He said that when an out-of-state defendant is sued in state court, the fact that a small local business or a local individual is also joined as a defendant will give only "cold comfort." In "actual practice," he told the Subcommittee, the out-of-state defendant would have little confidence that its interests would be protected in the same way that they would be in federal court. ${ }^{53}$

I agree with Mr. Stoffelmayr that the assumption underlying the forum defendant rule is open to question, particularly when the out-of-state defendant is the primary defendant (for example, the manufacturer of the drug the plaintiff ingested) and the in-state defendant is a local merchant or employee. The problem is that any overlap between the circumstances that allow for snap removal and those that would justify relaxing the forum defendant rule is completely coincidental. For example, in the medical-device cases described by Ms. Relkin, there is only one defendant, and that defendant is an in-state corporation. ${ }^{54}$ As long as the forum defendant rule is retained in its present form, it is hard to justify allowing ad hoc circumvention in situations where defendants can monitor state-court dockets electronically or where state law does not allow plaintiffs to perfect service quickly. 55

Out-of-state defendants may have a legitimate grievance if, under current law, plaintiffs can assert frivolous or insubstantial claims against an in-state defendant and use those claims to frustrate the right of removal that an out-ofstate defendant would have if sued alone. ${ }^{56}$ If so, the solution is to reform the law

53 This exchange begins at about I:06 in the webcast cited supra note I.

54 That was also the situation in the Third Circuit case that held snap removal permissible. See Encompass Ins. Co. v. Stone Mansion Restaurant Inc., 902 F.3d I47, I49 (3rd Cir. 2018).

55 As Professor Pfander put it, "[no] sensible system of jurisdictional allocation would foreclose removal by forum defendants and then create an exception for nimble docketmonitoring forum defendants."

56 In an article aimed at plaintiffs' lawyers, the author stated: "Plaintiff attorneys too often focus their attention on 'target defendants,' even though others may also be liable for their clients' injuries. ... You should therefore consider suing [non-diverse defendants], regardless of whether you anticipate receiving a substantial recovery from them, in order to keep your lawsuit in state court." Erik Walker, Keep Your Case in State Court, Trial, Sept. 2004, at 22. 
of fraudulent joinder, not to reject the snapback. ${ }^{57}$ There may be a kind of rough justice if some defendants take advantage of snap removal while some plaintiffs benefit from artful joinder. ${ }^{58}$ But two wrongs do not make a right, and Congress should not be satisfied with rough justice. It should seek to enact carefully crafted legislation that addresses each problem in a way that respects the purpose of the constitutionally authorized diversity jurisdiction.

Finally, Mr. Stoffelmayr commented that there is "no ... unfairness or injustice that would justify rewriting statutory language that has served the courts well for decades." I agree with that also, and that is why I oppose the suggestions outlined in Professor Pfander's statement. But the snapback proposal would not rewrite any statutory language; it would add a new, narrowly tailored provision that would deal with snap removal without upsetting other aspects of removal law.

\section{Clarifying the Law of Federal Jurisdiction: Finding a Better Process}

In his written statement and his oral testimony, Professor Pfander called attention to the fact that snap removal is only one of many issues in removal practice that have given rise to conflicting decisions in the lower courts. ${ }^{59}$ These

57 In 2016 and again in 2017, the House passed legislation aimed at modestly strengthening the fraudulent joinder doctrine. See Innocent Party Protection Act, H.R. 725, II 5 th Cong. (20I7); H.R. Rep. II5-I7 (20I7).

58 The term "artful joinder" is used here because of the parallel to the doctrine of "artful pleading." The artful pleading doctrine embodies the principle that "a plaintiff may not defeat removal by omitting to plead necessary federal questions." Rivet v. Regions Bank of La., 522 U.S. 470, 475 (1998) (internal quotation omitted) (emphasis added). In the cases referenced by Mr. Stoffelmayr, the plaintiff seeks to defeat removal by joining unnecessary defendants - unnecessary in this sense: if the plaintiff has a valid claim at all under the applicable law, he or she will ordinarily be able to obtain full redress from other defendants, and in particular the out-of-state corporation.

At the hearing in November 2019, the Ranking Member of the Subcommittee, Rep. Martha Roby, spoke in a similar vein. She said that plaintiffs often join non-diverse parties who "are not necessary to the litigation and at times are only included to keep ... a case in a state court that maybe seems favorable to the plaintiff." See https://www.law360.com/articles/ I242I2I/newhouse-bill-fights-snap-removals-to-federal-court.

59 Professor Pfander gave as an example the question of what parties must do to consent to removal under 28 U.S.C. I446(b)(2). See Crowther v. Mountain Productions, Inc., 2019 WL $3288137 * 3-* 4$ (E.D. Pa. July 22, 2019) (noting that four circuits "have held that a statement in one defendant's timely notice that its codefendant or codefendants have consented to removal is sufficient," but that three circuits have rejected that rule). Courts also disagree over what constitutes an "other paper" that triggers the second removal window under $\S$ I446(b)(3). 
unsettled issues add to delay, burden courts, and impose costs on the parties, without advancing resolution of the underlying disputes. Professor Pfander suggested that we "start a conversation about broadening the Rules Enabling Act, 28 U.S.C. $\S 2702$, to assign some authority over the details of removal and remand procedure to a rule-making body within the Judicial Conference of the United States."

I agree with Professor Pfander that the present process for addressing problems in removal and remand procedure leaves much to be desired. Indeed, the same can be said of federal jurisdiction generally, though removal is certainly an area particularly in need of study and reform. ${ }^{60} \mathrm{I}$ also agree with the suggestion that Congress should look to the Judicial Conference of the United States for assistance in addressing these matters.

Perhaps out of (unnecessary) modesty, Professor Pfander did not mention that there already exists an entity within the Judicial Conference that is empowered to study matters of federal jurisdiction and make recommendations for amendments to the Judicial Code. That is the Committee on Federal-State Jurisdiction; 61 for several years, Professor Pfander served with distinction as consultant to the Committee. The most far-reaching package of revisions to the basic jurisdictional statutes since 1990 - the Federal Courts Jurisdiction and Venue Clarification Act of 20I I (JVCA) - originated in a proposal presented by the Committee at a hearing held by this Subcommittee in 2005.62 The most

Compare Morgan v. Huntington Ingalls, Inc., 879 F.3d 602, 6I2 (5th Cir. 20I8) (the "removal clock begins ticking upon receipt of the deposition transcript"), with Huffman v. Saul Huffman Ltd. Partnership, I94 F.3d 1072, 1078 (I0th Cir. 1999) ("the removal period commences with the giving of the testimony, not the receipt of the transcript").

60 A good example, not involving removal, is "the law around cross-appeals," which a recent commentator described as "still unclear, obscure and evolving." Michael Soyfer, Patent Decision Highlights Cross-Appeal Considerations, Law360, Dec. 3, 2019, https://www.law360.com/articles/I224083/print?section=aerospace.

61 As a hierarchical matter, it should be noted that the Committee makes its recommendations to the Judicial Conference, which must approve them before they can be transmitted to Congress.

62 See Federal Jurisdiction Clarification Act: Hearing Before the Subcomm. on Courts, the Internet and Intellectual Property of the House Judiciary Comm., I09th Cong. (2005) [hereinafter JVCA Hearing]. Judge Janet Hall testified on behalf of the Judicial Conference committee. I also testified. At that time, venue reform was not part of the proposed legislation. 
important components of the JVCA were those relating to removal jurisdiction and procedure. ${ }^{63}$

Unfortunately, the current mode of operation of the Federal-State Jurisdiction Committee includes several features that substantially diminish the Committee's effectiveness as a forum for identifying problems and proposing solutions. The Committee itself is almost invisible. Neither its mission nor its membership is described on the Judiciary website. 64 The Committee makes no public announcements of its agenda or its proposals. For example, after the 2005 hearing, when the Committee unveiled the first version of the bill that became the JVCA, there was no further public disclosure of revised versions or of the many issues that arose as the bill made its way to approval by Congress and the President. 65

The JVCA provides a good illustration of the possible consequences of a closed process. At the 2005 hearing, the Judicial Conference offered a pair of proposals that would have allowed a plaintiff to avoid removal based on diversity jurisdiction by filing a "declaration" (i.e. stipulation) reducing the amount in controversy below the minimum specified in 28 U.S.C. $\S$ I332(a). This was an innovative approach that would have helped to "avoid needless litigation over the proper forum for [a diversity] case." 66 But the provisions were deleted from the final version of the bill because they had generated controversy. ${ }^{67}$ If the debate

63 See Arthur D. Hellman, The Federal Courts Jurisdiction and Venue Clarification Act Is Now Law, Jurist, Dec. 30, 20I I, https://www.jurist.org/commentary/20I I/I2/arthur-hellman-jvca/.

64 A press release issued on October I, 2019, announced that Chief Justice Roberts had appointed a new chair, Judge D. Michael Fisher of the Third Circuit Court of Appeals. Judge Fisher's appointment was effective on the same day.

65 There was some vetting, but it was not public. As the House Judiciary Committee report on the bill noted, the Administrative Office of US Courts (AO) functioned "as a clearinghouse to vet the bill and newly-developed revisions to it with the Judicial Conference's Federal-State Jurisdiction Committee, academics, and interested stakeholders." H.R. Rep. II 2-10 at 2-3 (20I I). But all of those communications were private, and lawyers and judges outside the tight circle had no way of knowing even what issues were being contested, let alone what changes were being made.

66 JVCA Hearing, supra note 62, at I4 (statement of Judge Hall). See also id. at 43 (statement of Arthur D. Hellman) (endorsing proposals).

67 See Arthur D. Hellman, The Federal Courts Jurisdiction and Venue Clarification Act: Some Missing Pieces, Jurist, Jan. 4, 2012, https://www.jurist.org/commentary/2012/0I/arthur-hellmanjvca-ii/ (noting that "any provision that generated any controversy was simply dropped from the bill'). 
had taken place out in the open, with a larger number of participants, it might have been possible to find common ground, at least on a narrow version of the idea.

I think there is a better way. This is not the place for a detailed proposal, but here are some steps that the Federal-State Jurisdiction Committee could take that would enhance its ability to help Congress in addressing jurisdictional issues:

- The Committee could periodically announce its agenda - matters that it is actively considering for possible recommendations.

- When a proposal has reached a sufficiently mature stage, the Committee could post it on the Judiciary website and invite comments.

- The Committee could invite judges, lawyers, and scholars to submit suggestions about aspects of federal jurisdiction that have given rise to confusion, conflict, or uncertainty in the lower courts.

- The Committee could establish a web page that would serve as a forum for judges, lawyers, and other interested persons to discuss jurisdictional problems and vet possible solutions.

Two caveats are in order. First, I am not suggesting that Congress should delegate authority to the Judicial Conference to promulgate rules governing matters of federal jurisdiction. There may be narrow issues on which delegation is appropriate; for example, Congress has authorized the Supreme Court to prescribe rules that "define when a ruling of a district court is final for the purposes of appeal under [28 U.S.C. § I29I]." 68 But when it comes to civil litigation, even technical rules about district court jurisdiction may involve policy choices that plaintiffs and defendants will view differently. Jurisdictional rules may also implicate questions of federalism - the allocation of judicial power between the national government and the states. ${ }^{69}$

68 See 28 U.S.C. $§ 2072$ (c). This provision was enacted in 1990. No rules of that kind have been adopted. The 1990 law also authorized the Supreme Court to promulgate rules defining new categories of interlocutory appeals. See 28 U.S.C. § 1292(e). One such rule, authorizing appeals from orders granting or denying class certification, has been adopted. See Rule 23(f) of the Federal Rules of Civil Procedure.

69 Justice Felix Frankfurter liked to quote former Justice Benjamin Curtis: "[Q]uestions of jurisdiction [are] questions of power as between the United States and the several States." Irvin v. Dowd, 359 U.S. 394, 412 (1959) (Frankfurter, J., dissenting) (citation omitted). 
Congress, as the representative branch of the national government, should retain ultimate authority to decide what the law of federal jurisdiction will be. But if the Judicial Conference submits proposed legislation that has been endorsed by the Federal-State Jurisdiction Committee after input from the bench and bar, Congress could move forward with confidence that the hard issues have been dealt with. Vetting by interest groups and scholars would also help to minimize the prospect of unintended consequences.

Second, I would not suggest that the Committee on Federal-State Jurisdiction should adopt the complete panoply of procedures followed today for rulemaking under the Rules Enabling Act. The Committee can borrow some elements of that process, but there is no need for such an elaborate set of protocols when the Committee would only be making recommendations to Congress.

To continue the conversation that Professor Pfander invited, I will suggest that a good first step would be for the Chairman and Ranking Member of this Subcommittee to write to Chief Justice Roberts, in his capacity as Chair of the Judicial Conference, expressing a desire that the Committee on Federal-State Jurisdiction take on a more robust role in considering jurisdictional issues and making recommendations to the House and Senate Judiciary Committees. The letter could specify some of the steps the Committee could take and perhaps even identify some issues that have come to the Subcommittee's attention. There is precedent for such a letter; in 2002, after a hearing on the operation of the federal judicial misconduct statutes, the Chairman and Ranking Member of the Subcommittee wrote to Chief Justice Rehnquist offering "recommendations ... to improve the operations of Article III courts and instill even greater confidence in [the courts'] work."70

That is a suggestion for the longer term. For now, I urge the Subcommittee to move forward with the snapback legislation - a targeted measure that would deal with a narrow problem without disrupting other aspects of removal practice or foreclosing Congress's options if it should want to consider more widely applicable reforms in the future.

70 The letter is reprinted in H.R. Rep. 107-459 at I6-I8 (2002). 